(c) 2001 Plant Health Progress.

Accepted for publication 1 February 2001. Published 5 February 2001.

\title{
Occurrence and Distribution of Aphis glycines on Soybeans in Illinois in 2000 and Its Potential Control
}

\author{
G. L. Hartman, L. L. Domier, and L. M. Wax, USDA, Agricultural \\ Research Service; C. G. Helm, D. W. Onstad, J. T. Shaw, L. F. \\ Solter, and D. J. Voegtlin, Illinois Natural History Survey; C. J . \\ D'Arcy, M. E. Gray, and K. L. Steffey, Dept. of Crop Sciences; S. A. \\ I sard, Dept. of Geography; P. L. Orwick, National Soybean \\ Research Laboratory, University of Illinois, Urbana, IL 61801 \\ Corresponding author: G. L. Hartman. ghartman@uiuc.edu
}

Hartman, G. L., Domier, L. L., Wax, L. M., Helm, C. G., Onstad, D. W., Shaw, J. T., Solter, L. F., Voegtlin, D. J., D'Arcy, C. J., Gray, M. E., Steffey, K. L., Isard, S. A., and Orwick, P. L. 2001. Occurrence and distribution of Aphis glycines on soybeans in Illinois in 2000 and its potential control. Online. Plant Health Progress doi: 10.1094/PHP-2001-0205-01-HN.

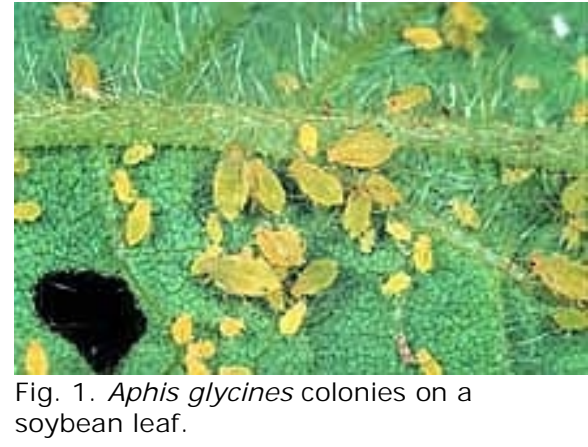

During August of the 2000 growing season, Aphis glycines Matsumura, an aphid native to Asia, was found colonizing soybean plants in Illinois (Fig. 1) (1,2). Hundreds of aphids were observed on every leaflet on plants in some fields in northern Illinois. Within 3 weeks of the initial observation, A. glycines was found at lower population densities in most central and southern Illinois locations including the southernmost county in the state (Fig. 2). While conducting the aphid survey in Illinois, aphids were collected from about half the counties in the state. These collections will be used for molecular typing and virus transmission studies. By the end of the 2000 season, A. glycines was found in most states in the midwest, and coincidentally, it was reported for the first time in Australia (3).

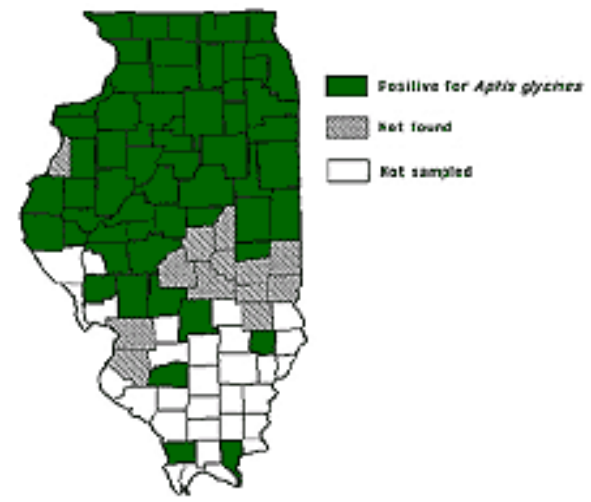

Fig. 2. Distribution of Aphis glycines in Illinois in 2000. 


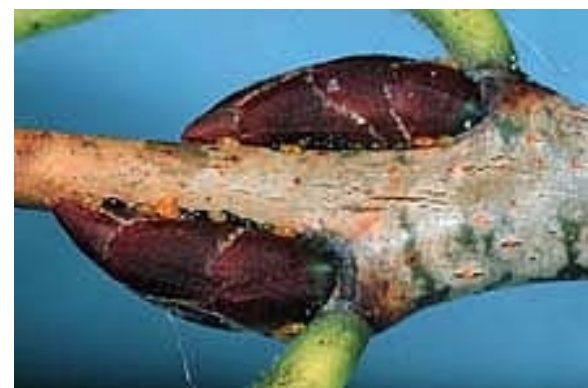

Fig. 3. Eggs of Aphis glycines on buds of Rhamnus cathartica.
In temperate regions, A. glycines has a complex life cycle involving two hosts. Sexual stages deposit eggs for overwintering on the primary host, Rhamnus spp. (buckthorn) (Fig. 3). In the spring, winged aphids fly from Rhamnus in search of soybean fields. On soybean plants, the aphid produces both wingless and winged adults, the latter contributing to geographic spread of the aphid. In the fall, winged individuals move back to Rhamnus. Both winged adults and eggs were

observed on R. cathartica in the fall of 2000. In addition to R. cathartica, there are three native Rhamnus spp. and two introduced species that could potentially serve as overwintering hosts.

Many viruses present in the U.S. have the potential to be transmitted by A. glycines including Soybean mosaic virus (SMV), one of the most common soybean viruses in Illinois. Our attempts to transmit SMV by A. glycines have been unsuccessful. However, not all strains of SMV are aphid-transmissible and further studies are underway to determine if different strains of SMV, as well as other soybean-infecting aphid-transmitted viruses, can be transmitted by A. glycines.

Natural enemies, including predators and entomophthoralean fungi, may be important in controlling A. glycines. High densities of lady bird beetles, including Harmonia axyridis, an exotic species from Asia, were observed in northern Illinois soybean fields. Observations and collections of A. glycines suggested that entomophthoralean fungi were causing localized epizootics. One aphid pathogenic fungus, Pandora sp., was isolated and is being further characterized.

Because A. glycines had not been previously documented in the U.S., no insecticides are registered in the U.S. for its control. An insecticide efficacy trial was established in a soybean field in Carroll County (northwestern Illinois) on August 26, 2000. At the start of the trial, there was an average of 45 aphids counted per leaflet. Plots were laid out in a randomized complete block with four replications. The treatments included two untreated controls and different rates of seven insecticides (Asana XL, Dimethoate 4EC, Lannate SP, Lorsban 4E, Penncap-M, Pounce 3.2EC, and Warrior T) registered for soybeans in the U.S. Aphids were counted at 3 and 10 days after applying treatments (DAT). The average density of aphids in the untreated control plots increased 2.7-fold by 3 DAT, but declined before 10 DAT as a possible result of natural dispersion, predators, or entomophthoralean fungi. Treatments of Dimethoate, Lannate, Lorsban, Penncap-M, and Warrior (0.025 lb a.i./ acre) decreased aphids densities by more than $90 \%$ at 3 DAT. Additional studies are needed to determine the potential for limiting the growth of colonizing aphid populations and the effects of insecticides on nontarget organisms.

In addition to current research on A. glycines, further research is being planned to study the basic biology of the aphid including monitoring its movement, the impact it has on yields, its importance as a vector of soybean viruses, and potential management strategies.

\section{References}

1. Steffey, K. L. 2000. More news on the soybean aphid in Illinois. Online. The Pest Management and Crop Development Bulletin, University of Illinois, Urbana, Illinois.

2. Voegtlin, D. J . Soybean aphid discovered in Illinois. Online. Center for Biodiversity, Illinois Natural History Survey, Champaign, Illinois.

3. Fletcher, M. J. and Desborough, P. 2000. The soybean aphid, Aphis glycines, present in Australia. Online. Agricultural Scientific Collections Unit, Orange Agricultural Institute and the Agricultural Research and Advisory Station Scientific, Australia. 